BMC JOURNAL OF SCIENTIFIC RESEARCH

A Multidisciplinary Research Journal

ISSN: 2594-3421

\title{
Women as Phenomena and Men as Sensors in Women's Magazines
}

\author{
Mukti Nath Kandel * \\ muktinkande143705@gmail.com
}

\begin{abstract}
This article is an attempt to examine the process of constructing gender roles in society through the women's magazines. As its title suggests, it examines how female participants, from Nari (e-kantipur publication) have been projected as objects of male gaze (phenomena) and males as the agents of gaze (sensors). Even though such magazines are labeled as "women's magazines," the agenda setter and the gatekeeper are certainly the males since the female represented participants are prepared hegemonically to satisfy the male desire. The paper concludes that women are largely depicted and assigned to play four gender stereotyped roles: home decorators, child nurturers, cooks, and persons whose attention is always drawn to their bodies away from their minds.
\end{abstract}

Keywords: gender roles, phenomena, represented participants, sensors, hegemony

Although there are physical and psychological differences between most females and males, there are more similarities between them than there are differences. The differences are over emphasized by the today's capitalist society so that they can sell the face whitening gel separate for females and males. Women are depicted as if they were from Mars and men from another planet. To perpetuate this idea in the human society, varied views are found about the idea of gender and sex. Sigmund Freud claims that biology determines one's destiny and asserts that "gender is the product of sexual maturation" (187-192). He further argues that girls demand to be loved and become victims of shame, narcissism and vanity. In other words, girls lack something but boys do not (191). Critiquing Sigmund Freud, Rosemary Tong contends that Freud's ideas have been influenced and shaped by the so-called biological determinism - anatomy is destiny - that means human beings' reproductive roles, gender identity, sexual preference and orientations etc., are determined by their anatomy. The psychoanalysts focus too much on the inner dynamics of the psyche, the speculative space of human body, rather than on the external permutations of society as the primary source of gender construction. They emphasize only one kind of family - the capitalist, middle class, white, heterosexual, and nuclear family - as the paradigm for all kinds of family. Tong further argues "it is not clear that single parent family, lesbian or homosexual parent will have the same results in children's sexual lives" (175-158). These psychoanalytic thinkers often conflate the families they know best with the family, a universal construct that never has or will exist.

\footnotetext{
* M.N. Kandel is Teaching Assistant in English at Birendra Multiple Campus (Tribhuvan University)
} 
Lacan opines that feminine sexual pleasure cannot be known because it cannot be expressed in phallic language (64-66). For Lacan, it is the biology of the female child that excludes her from the male symbolic order. Reacting Lacan's formulation, Luce Irigaray contends that if a woman tries to express her pleasure, he excludes her, because she challenges and upsets his system, and in "phallic signifying economy" (91) only men can say what female sexual pleasure is. Regarding this issue, Michel Foucault concentrates his attention mainly to aspect of sexuality in his The History of Sexuality. He considers "sexuality" and "knowledge about sexuality" as regulatory regimes. He takes the same approach to "sexuality" as he has defined "madness". He treats sexuality not as a thing, a natural reality, but as the instrument and effect of an entire series of discursive and political strategies (105). Cameron and Kulick view sexuality as having a broader scope than that. For them, all kinds of erotic desires fall within the scope of the term. Any inquiry into sexuality (whatever else it may take to be relevant) should have something to say about sex, i.e. erotics (xi). In other words, sexuality is socially constructed expressions of erotic desires (4-8). It has a lot to do with the social aspect.

The publication of Laura Mulvey's article "Visual Pleasure and Narrative Cinema" has a huge impact on gender representation. She argues that one of the pleasures of cinema is scopophilia, a voyeuristic gaze directed at other people. A second form of pleasure, she argues, is a narcissistic voyeurism -seeing oneself as a primary character and identifying with them (9-10). Mulvey's article ignores the most dynamic and volatile aspects of human sexuality and tries to reduce it into scopophilic voyeurism and male gaze. Power is clearly a key consideration here. Stereotypes tend to be directed at subordinate groups (ethnic minorities, women) and they play an important part in hegemonic struggle because the discourse, in question, is controlled by the powerful and dominant group. Talbot states that hegemony involves control by consent. Stereotypes are reproduced in a wide range of practices of representation, including scholarship, literature, and television (471). In advertisements stereotypes are produced by the juxtaposition of one group of people with one set of items. Women are often depicted with the advertisements of washing powder; men with cigarettes and alcoholic products.

Sara Mills, in her Feminist Stylistics, integrates the ideas of feminism and stylistics in order to analyze media discourses and magazines. She also analyzes the textual as well as visual messages in the magazines contending that most of the magazines are made from the male mindset. The primary purpose of these magazines is to entertain male readers rather that information-transfer (32). This is also the continuation of the hegemony long practised. Susan Dente Ross, in her article "Marking and Demarking: Images, narratives and Identities" deals with the power of images in the media. She also describes how media discourse in their textual and visual messages create stereotypes and prejudices (1-5). Similarly, Steuter and Wills, in their article "The Dangers of Dehumanization" deal with the images as metaphors that differentiate people into categories and they also describe how media discourses systematically stereotype and dehumanize people (43-54). When media does not realize the role to change, it merely acts as the agent of the dominant ideology. 
In their work "Selling Sex," Lisa Wade and Gwen Sharp contend that women's stereotyping can be realized through the images in which they are objectified (163). They add "objectification is problematic because making women into things erases their desires. Objects do not have feelings or preferences. Things do not have opinions, and they cannot disagree. If someone desires them, they can be had" (165). The flipside of the sexual objectification of women is the affirmation of men's sexual subjectivity. When a woman is sexually objectified, she is made into an object for someone. Much of the time, that someone is a heterosexual man. Talking about the stereotyping process, they add, "just as the objectification of women specifies one very narrow version of sexiness, men are taught that only one type of sexuality is acceptable" (165). And nothing other than that is allowed and acceptable.

John Berger's work Ways of Seeing plays a vital role in exploring the stereotyped images in magazines. A woman's presence in the media (on the glossy pages of a magazine), as Berger asserts, is that of the "surveyed" and by contrast a man's presence is that of a "surveyor" (46). He sums up the entire thesis of his book by saying that "men act and women appear" (47). He elaborates this further as men look at woman; women watch themselves being looked at them. Mulvey also expresses her views in a similar way (this is stated earlier in this review). Moreover, Anthony J. Cortese, in his work Provocateur: Images of Women and Minorities in Advertising, makes an extensive study on how gender and racial stereotypes are constructed in visual and textual messages of magazines and other media. He juxtaposes how men and women are depicted differently as if they were from different planets. He elaborates the idea of symbolic racism and sexism in the media. He also demonstrates how female body is dismembered and cropped to damage its integrity.

While some of the critics advocate the notion of binarism, the classification clearly incorporates the power play. The schemes of classification are prepared by the subjectivities that are truly narcissistic. The narcissistic lenses are more like the colored glasses that can't discriminate the realities. In the case of the gendered stereotypes, the fixation of female's identity is another violation on women's identity- related spaces, this research alienates itself to the analysis of Nari, a popular women's magazine in Nepal. Distinctly, even the women's magazines such as Nari are not free from the debased women's identities.

David Gauntlett, in his book Media, Gender and Identity, deals with the female identity in women's magazines in British media. He traces the history of women's magazines in Britain in the twentieth century. He also deals with the changing attitude of women towards sex and glamour. He brings in his discussion the women's magazines such as Cosmo, Glamour, and More where today's women's interest about girl power and body politics is different from that of the earlier times (190-198). The shift in the interest can be noted as the paradigm shift. In this paper, I have tried to analyze the commercial advertisements in women's magazine Nari in which the female participants have been projected as objects of male gaze (phenomena) and males as the agents of gaze (sensors). Although Nari, the women's magazine published in Nepal claims to fight for gender equality, it contributes to perpetuate the age-long stereotyped 
idea that women appear and men act developed by John Berger and Mary Wollstonecraft long time back in history. The advertisement in this magazine portrays the image of women as passive sexual objects to be looked at and the males as the principle viewers. On the contrary, the publication manifesto of ekantipur publication claims:

Nari wants to help the culture of reading and writing flourish among Nepali women. It encourages female writers to contribute regular columns, urges in-house writers to quote female experts, gives priority to articles written by female writers and promotes articles written by men on women's issues. The magazine wants to analyse the social, political and economic status of Nepali women, capture the essence of womanhood and fight for gender equality.

Though the magazine claims to capture the essence of womanhood and fight for gender equality, the agenda setter in the magazine are certainly the males. In reality, the female represented participants in this magazine are prepared to satisfy the male desire. The images that appear in this magazine represent women as passive objects of sexual desire.

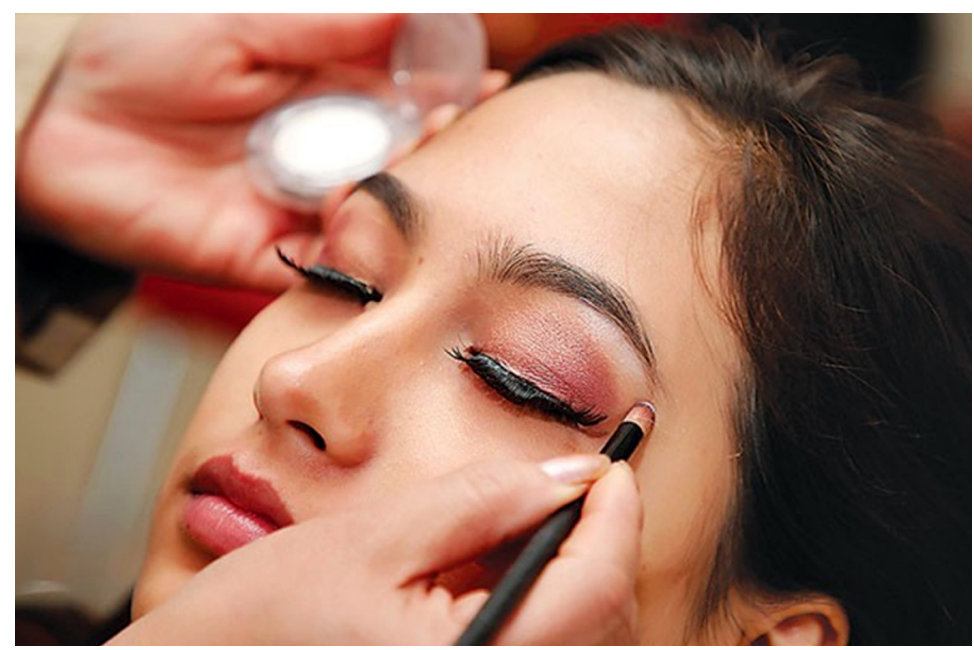

Fig.1. (Nari http://nari.ekantipur.com 12)

The image depicted in Fig. 1 from the women's magazine depicts a young woman decorating her face with cosmetic stuff. The basic purpose of this act is, largely, to depict this woman through the close shot implying that she appears to be within viewer's close tactile impression in the imaginary level so that the viewers can have their sensor's roles. This image is largely depicted for male gaze. Though no male participant is depicted for female gaze in the men's magazines, the images in women's magazines such as Nari provide the male participants'/ viewers' immediacy of experience and pleasure. In this image, male participants are owner of the gaze and the female participant is an object of male gaze. This image is intentionally made to be looked upon by male participants in which the image of a young woman decorating her face is portrayed as inactive, passive and submissive. It is intentionally prepared to nurture the presupposed male participants' sense of possession and control. 


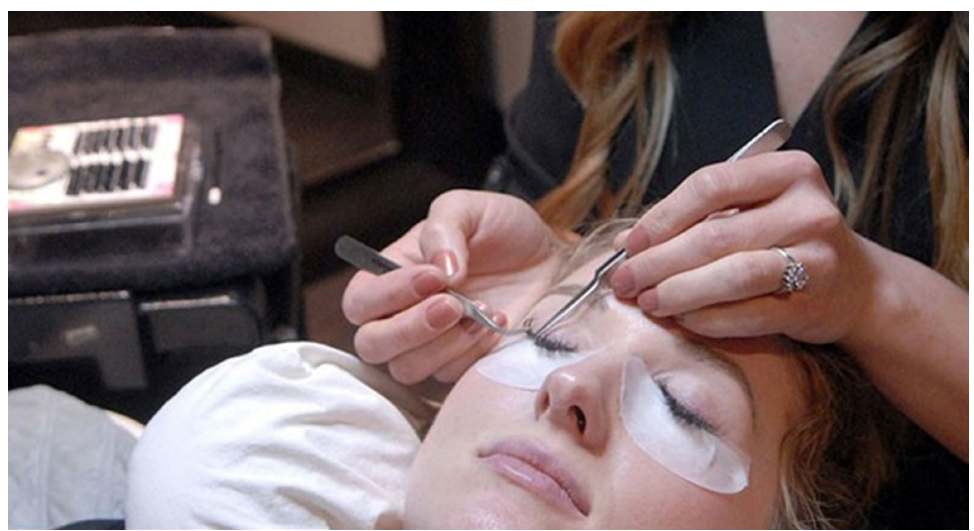

Fig. 2. (Nari http://nari.ekantipur.com 32)

The image depicted in Fig. 2 shows the image in which female participant is merely an object to gaze. This image is intentionally prepared to fulfil the desire of males. Her eyes are closed as she lacks the agency of gaze. Her eyes are closed in order to prepare a secure position for the voyeuristic male gaze. This act creates pleasure of looking for the males. In this image, the "scipophilia" or the pleasure of looking is central issue to satisfy males. The way her image is prepared can be analyzed as if she is beautifying herself to fulfil sexual lust of male. Though image of a woman appears in the magazine, it has presupposed the male gaze. She cannot open her eyes and as such she is passive and submissive. She lacks look of her own because of her lack of agency.

Another female person is there to prepare this female so that she becomes the perfect object (so attractive and delicate) for (male) caresses. Though males are absent in the image, they are supposed to be watching her image. This image cannot defy male gaze as she is prepared as an object of visual pleasure of males. She has been projected as object of male gaze, merely phenomena. Males who are absent in the image are the agents of gaze. Because of this reason, the female in this image is prepared beautiful not for herself but for another to be an object of visual pleasure. Even though the women's magazines like Nari claim to empower women, they are, in fact, perpetuating the stereotyped gender roles assigned to women by the society for centuries in terms of beauty, softness and elegance. When one makes an inventories of all the images depicted in Nari, one finds that women are grossly assigned four main roles: home makers, child nurturers, cooks, crazy person to pay her attention to the body away from her mind.

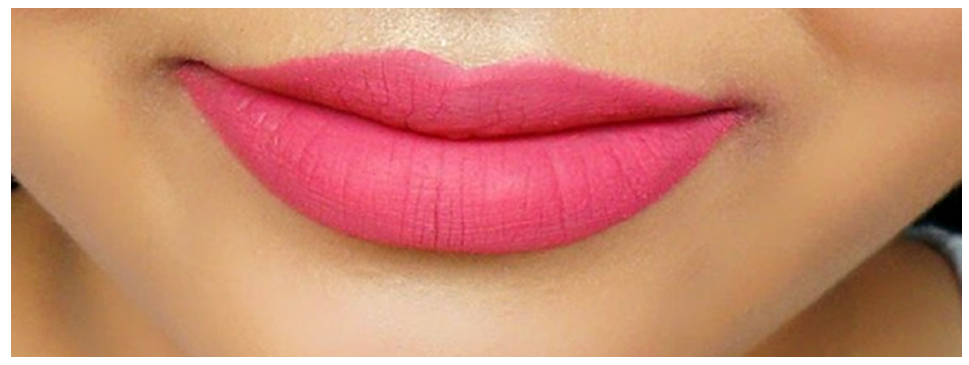

Fig. 3 (http://nari.ekantipur.com) 
In Nari (Nov. 16, 2013 /Mangsir 8, 2070 (B.S.), this image appeals to every woman to come forward for equality and coexistence with their male counterpart. This commitment may sound logical in itself. But if one juxtaposes it against the textual and visual messages presented / packaged in this magazine, one finds that women are allocated very limited roles (assignments). The roles include, along with others, home making, fashioning, body decorating, child care, culinary care, and entertaining her male partner. As depicted in Fig. 3, the image is a dismembered, fragmented and focalized part of a female body. This image is to be censored by a (male) person available to be kissed. At the same time the holistic wholeness is snatched, and part is catered for indulgence. By performing this type of role woman will never enjoy their equality with their male counterparts.

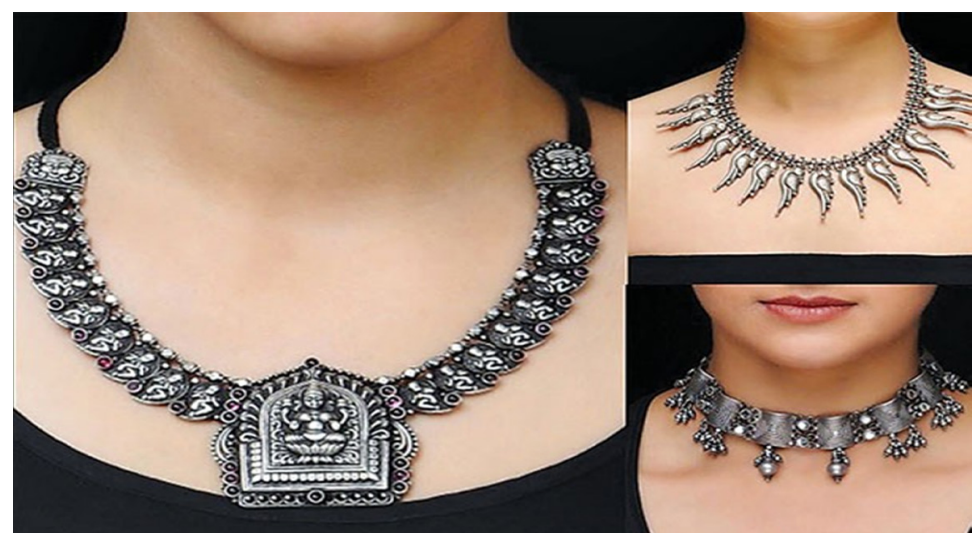

Fig. 4 (http://nari.ekantipur.com)

What is more, these magazines seem to reflect the reality of handfuls of women in Nepal in terms of class (elite), color (fairer), region (center/ city), age (young and / or middle), caste / ethnicity (mainly, Aryan), profession (home makers), physical ability (differently able people are excluded from the agenda), sexual orientation (heterosexual) and religion (mostly Hindu). In other words, these magazines have homogenized and stereotyped women. Even if they claim to work for all women kind, the visual and textual contents of these magazines represent the reality of very limited number of women. As stated earlier, the attention of women is drawn towards their body away from their minds. As depicted in Fig. 4. the jewelries of the woman's neck indicates that it reflects the reality of upper/middle class, young-to-middle aged, city-bred women and it does not, in any way, reflect the reality of an average Nepali women, despite the fact that it claims otherwise.

By and large, the magazine serves the purpose /interests (economic, psychological, cultural, and social) of the male-led ideology and consumerism and capitalism. So, in order to accomplish these functions, women (female bodies) are stereotyped, distorted, dismembered, focalized and "politicized."

The depiction of the female body in advertising is basically for the purpose of selling sex (the female "marked" body) and for enhancing and embellishing the product. The female body even 
in the so-called women's magazines is depicted more like a phenomenon/goal than an agent/ actor. The male body is in most part depicted for the purpose of executing the action as an actor/ agent rather than as a phenomenon. This type of depiction may have deeper and long-term impact on the interlocutors/viewers: it may be one of the factors which may cause women to view themselves in a negative and stereotyped way; and it may discourage female participants to execute any work as an agent or actor.

The participants involved in the processes of production, distribution and reception of these ads, on the main, are men because it is they who have more control over the access to economic resources and information in comparison to women. Even if men are not depicted in the images, they are everywhere: as the manufacturer, producer, director, camera person, distributor, buyer/consumer, reader/viewer and so on. Women participants have to work within the agenda set by men.

In short, women are presented as phenomenon and men as sensors in Nari. Most of the images are juxtaposed with the cosmetic products, interior parts of the house, child care, food, fashion, and beauty products. Such images of women are on display and as such they are increasingly sexualized. These women are rarely depicted with workplaces such as engineering, medical science, hospitals, aeroplanes and other careers. There is nothing wrong with women being and appearing beautiful. The final point is how a magazine is empowering women by assigning the traditional gender roles so that women will be confined within the four walls of their homes.

\section{References}

Berger, John. Ways of Seeing. London: Penguin, 1972. Print.

Cameron, Deborah, and Don Kulick. Language and Sexuality. Cambridge: Cambridge University Press, 2003. Print.

Cortese, Anthony J. Provocateur: Images of Women and Minorities in Advertising. Lanham, Maryland: Rowman and Littlefield, 1999. Print.

Foucault, Michael. Discipline and Punishment. London: Tavistock, 1977. Print.

Freud, Sigmund. Sexuality and the Psychology of Love. New York: Collier Books, 1968. 187-192. Print.

Gauntlett, David. Media, Gender and Identity. London and New York: Routledge, 2008. Print.

Irigaray, Luce. “Women's Exile: Interview with Luce Irigaray.” Trans. Couze Venn. Cameron. 80-89. Print.

Kantipur Publication. Nari http://nari.ekantipur.com accessed on 20th November 2018. Print.

Lacan, Jacques. Ecrits: A Selection. Trans. Alan Sheridan. New York: W.W. Norton, 1977. 64-68. Mills, Sara. Discourse. London: Routledge, 1997.Print.

Mulvey, Laura. "Visual Pleasure and Narrative Cinema." Screen 16.3 (1975): 6-18.Print.

Ross, Susan D. Images That Injure. London: Praeger, 2001. Print.

Steuter, Erin, and Deborah Wills. "The Dangers of Dehumanization: Diminishing Humanity in Image and Deed." Ross and Lester. 43 -54. Print.

Talbot, Mary. Media Representation. Edinburgh: Edinburgh UP, 2007. Print.

Tong, Rosemarie. Feminism: A Comprehensive Guide. London: Routledge, 2010. Print.

Wade, Lisa, and Gwen Sharp. "Selling Sex." Images that Injure. Ross and Lester. Pp. 163-172. Print. 